\title{
Uji Daya Simpan dan Efektivitas Prototipe Pupuk Hayati Mikoriza dengan Media Pembawa Pasir Vulkanik dan Pasir Laut
}

\author{
KADEK JUNIARI, I NYOMAN RAI*), DAN I MADE SUKEWIJAYA \\ Program Studi Agroekoteknologi Fakultas Pertanian Universitas Udayana \\ Jl. P.B. Sudirman Denpasar Bali 80232 \\ ${ }^{*}$ E-mail: inrai_fpunud@yahoo.com
}

\begin{abstract}
Time Storage and Effectivity of the Prototype of Mychorrhiza Biological Fertilizer with Volcanic and Sea Sand as the Carrier Media. This research aimed to study time storage and the efectivity of prototype of mychorrhiza biological fertilizer with volcanic and sea sand as the carrier media. The study was arranged using a randomized block design with 2 factors. The first factor was carrier media of mychorrhiza spore consist of 2 levels i.e. volcanic and and sea sand, and the second factor was time storage of prototype of mychorrhiza biological fertilizer consist of 3 levels i.e. 1, 2, and 3 month. The result of research showed that volcanic sand carrier media was better than the sea sand media proved by higher total dry weight. The best time storage of prototype of mychorrhiza biological fertilizer in this research was 1 month indicated by the highest amount of spores after storage. The interaction between carrier media and time storage gave significantly different just to stem diamater and fresh weight of corn cob.
\end{abstract}

Keywords: mycorrhiza, carrier media, storage time, corn

\section{PENDAHULUAN}

Tanaman jagung

$(Z e a$

merupakan salah satu tanaman pangan dunia yang terpenting, selain gandum dan padi. Hal itu disebabkan jagung memiliki nilai gizi yang baik serta kegunaan yang cukup beragam. Permintaan jagung terus meningkat dari tahun ke tahun sebagai akibat dari tingginya laju pertambahan penduduk dunia yang mencapai $1,4 \%$ per tahun (Agrofarm, 2014).

Dewasa ini sektor pertanian berkembang cukup pesat, namun disertai dampak negatif yang cukup berat, yaitu terjadinya pencemaran lingkungan yang disebabkan oleh penggunaan pupuk anorganik yang dapat menurunkan kualitas lahan sehingga produktivitasnya menurun. Selain itu dapat mengubah budaya petani 


\section{KADEK JUNIARI. et al. Uji Daya Simpan dan Efektivitas Prototipe Pupuk Hayati...}

yang hanya memperhatikan target produksi tinggi tetapi tidak menghiraukan efek yang ditimbulkan yaitu kerusakan lahan. Hal ini menyebabkan terjadinya pencemaran lingkungan yang mengkhawatirkan di antaranya adalah pencemaran terhadap sumber daya air dan lahan pertanian. Dampak lebih jauh dapat menyebabkan kerusakan tanah secara fisik, kimia dan biologis, dan pada akhirnya menurunkan kualitas dan kuantitas hasil pertanian. Untuk mengantisipasi hal tersebut dapat dilakukan dengan memanfaatkan fungi mikoriza arbuskula dalam menjaga kesuburan tanah dan dapat meningkatkan hasil produksi petanian.

Fungi mikoriza arbuskula (FMA) mempunyai kemampuan berasosiasi luas dengan berbagai jenis tanaman, sehingga banyak dimanfaatkan untuk mengatasi masalah kesuburan tanah marjinal (Musfal, 2010). Simbiosis antara tanaman dengan FMA adalah simbiosis mutualisme, di mana fungi mendapatkan karbohidrat dari tanaman untuk kelangsungan hidupnya, sedangkan tanaman dapat menyerap lebih banyak unsur hara terutama $\mathrm{P}$ (Chalimah, 2007). Mikoriza berperan dalam melarutkan $\mathrm{P}$ dan membantu penyerapan hara $\mathrm{P}$ oleh tanaman. Selain itu tanaman yang bermikoriza umumnya juga lebih tahan terhadap kekeringan, contoh mikoriza yang sering dimanfaatkan adalah Glomus sp. dan Gigaspora sp. Dalam pembuatan prototipe pupuk hayati diperlukan media pembawa dan penyimpanan prototipe pupuk hayati tersebut. Adapun tujuan menggunakan media pembawa dalam pembuatan prototipe pupuk hayati, yaitu untuk tempat hidup inokulum spora sebelum diaplikasikan dengan tujuan agar tetap hidup selama jangka waktu tertentu. Media pembawa yang sering digunakan seperti zeolit, kuarsa, dan gambut tersebut susah didapatkan, dan harganya mahal, sehingga perlu diganti dengan yang lokal yang mudah didapatkan, dan harganya murah atau terjangkau akan tetapi informasi tentang uji efektivitasnya belum ada, oleh karena itu penulis melakukan penelitian ini yang menggunakan media pembawa berupa pasir vulkanik dan pasir laut untuk pembuatan prototipe pupuk hayati mikoriza. Disamping itu, media pembawa pasir vulkanik dan pasir laut memiliki sifat yang sesuai dengan syarat-syarat media pembawa tersebut.

Mikoriza dapat berkembang dengan baik apabila tidak ada hambatan aerasi. Oleh karena itu, mikoriza dapat berkembang lebih baik pada tanah yang berpasir dibandingkan tanah liat (Natalia, 2016). Tanah berpasir dengan tekstur kasar dan unsur hara rendah, KTK tinggi sangat baik sebagai media 
tumbuh untuk produksi mikoriza. Mineral pasir vulkanik memiliki fraksi yang didominasi oleh sebagaian besar pasir dengan kejenuhan basa dan kandungan silika yang tinggi. Fungsi pasir vulkanik selain mampu memperbaiki struktur, mengurangi efek racun asam-asam organik dan lain sebagainya. Sedangkan pasir laut cenderung bersifat basa karena kandungan garamnya yang tinggi dan sedikitnya partikel liat. Efektivitas FMA juga dipengaruhi oleh kesesuaian jenis genotif tanaman, suhu, media tanam, lama penyimpanan, dan daya kecambah. Lama penyimpanan akan menurunkan viabilitas spora FMA. Spora merupakan propagul yang mampu bertahan hidup lebih lama dibandingkan dengan hifa yang ada di dalam akar ataupun di dalam tanah.

Informasi tentang daya simpan FMA dan efektivitas prototipe pupuk hayati mikoriza dengan media pembawa pasir vulkanik dan pasir laut sejauh ini jarang dilaporkan, maka dari itu penelitian ini dilakukan untuk mengetahui pengaruh daya simpan FMA dengan perbedaan waktu penyimpanan 1 bulan, 2 bulan, dan 3 bulan dan efektivitas prototipe pupuk hayati mikoriza dengan media pembawa pasir vulkanik dan pasir laut.

\section{BAHAN DAN METODE}

Penelitian ini dilaksanakan dari Agustus 2018 sampai Maret 2019. Tempat pengambilan sampel tanah adalah di Kabupaten Karangasem. Isolasi dan identifikasi endomikoriza dilaksanakan di Laboratorium Sumberdaya Genetik dan Biologi Molekuler Universitas Udayana. Uji daya simpan prototipe pupuk hayati dilaksanakan di Laboratorium Agronomi dan Hortikultura, Fakultas Pertanian, Universitas Udayana. Aplikasi prototipe pupuk hayati mikoriza dilaksanakan di Rumah Kaca Kebun Percobaan Fakultas Pertanian Universitas Udayana.

Alat-alat yang digunakan dalam penelitian ini, antara lain tissue, kantong plastik, kertas label, cawan petri, oven, mikroskop stereo, mikroskop compound, timbangan, gelas beaker, sendok, stoples, tabung sentrifius, mesin sentrifius, botol semprot, pipet mikro, pipet tetes, jarum oose, polybag, alat tulis, kamera serta satu set saringan dengan diameter lubang $1 \mathrm{~mm}, 500$ $\mu \mathrm{m}, 212 \mu \mathrm{m}, 106 \mu \mathrm{m}$, dan $53 \mu \mathrm{m}$. Bahan yang digunakan dalam penelitian ini adalah sampel tanah, pasir vulkanik, pasir laut, gula pasir, air, aquades, pupuk organik, benih tanaman jagung, $\mathrm{KOH} 10 \%, \mathrm{H}_{2} \mathrm{O}_{2} 3 \%$, HCL $1 \%$, lactogliserol, dan trypan blue. 


\section{KADEK JUNIARI. et al. Uji Daya Simpan dan Efektivitas Prototipe Pupuk Hayati...}

Penelitian uji daya simpan dan spora yang ditempatkan dalam 1 stoples/500 efektivitas prototipe pupuk hayati mikoriza g media pembawa, sehingga diperlukan dengan media pembawa pasir vulkanik dan jumlah spora keseluruhan, yaitu 3.600 buah pasir laut menggunakan rancangan acak kelompok (RAK) faktorial dengan 2 faktor spora (dalam 3 bulan).

Pada kombinasi perlakuan isolat perlakuan. Faktor pertama, jenis media tunggal genus Glomus dengan media pembawa/carrier terdiri atas 2 taraf: pasir pembawa (GV dan GL), masing-masing vulkanik (V) dan pasir laut (L). Faktor kedua, media pembawa dengan berat $500 \mathrm{~g} /$ polybag lama penyimpanan terdiri atas 3 taraf: 1 diberikan 100 buah spora Glomus, dikemas bulan $\left(S_{1}\right), 2$ bulan $\left(S_{2}\right)$, dan 3 bulan $\left(S_{3}\right)$. dalam stoples, lalu disimpan pada suhu Dengan demikian terdapat 6 perlakuan kamar. Pembuatan prototipe dan pelaksanaan kombinasi dan masing-masing diulang penyimpanan pada perlakuan penyimpanan 3 sebanyak 6 kali, sehingga terdapat 36 unit percobaan.

Eksplorasi dilaksanakan dengan mengambil sampel tanah dari tanaman salak, sampel diambil berasal dari tiga lokasi dan diambil tiga titik secara acak pada masingmasing lokasi, kemudian dikompositkan menjadi satu. Metode yang digunakan adalah metode tuang saring dari Pacioni (1992, Pangaribuan 2014) dan dilanjutkan dengan teknik sentrifius yang dimodifikasi.

Penghitungan jumlah spora endomikoriza awal dilakukan untuk menghitung jumlah spora pada tanah sampel yang diambil di lapangan sebelum dilakukan penyimpanan, yaitu menggunakan 1.200 spora Glomus/bulan selama 3 bulan. Setiap $500 \mathrm{~g}$ media pembawa pasir laut dan pasir vulkanik masing-masing berisikan 100 buah bulan $\left(S_{3}\right)$ dilakukan paling awal (3 bulan sebelum diamati), kemudian 1 bulan dan 2 bulan berikutnya baru dilakukan pembuatan prototipe pupuk hayati untuk perlakuan penyimpanan 2 bulan $\left(S_{2}\right)$ dan 1 bulan $\left(S_{1}\right)$.

Media pembawa yang digunakan yaitu pasir vulkanik dan pasir laut, media pembawa terlebih dahulu ditimbang sebanyak 500 g kemudian dimasukan ke dalam plastik yang sudah diberi lubang kecil untuk nantinya dilakukan pengukusan pada media pembawa. Pengukusan dilakukan selama \pm 40 menit dengan tujuan agar media pembawa yang digunakan seteril atau terhindar dari jamur dan patogen.

Media tanam nantinya dipakai untuk menguji efektifitasnya pada tanaman, yaitu campuran tanah dengan pupuk organik dengan perbandingan 1:1 yang kemudian 
ditimbang sebanyak $5 \mathrm{~kg}$ lalu dimasukkan ke dalam plastik yang sudah diberi lubang. Pengukusan media tanam dilakukan selama \pm 40 menit dengan tujuan agar media tanam terhindar dari mikroorganisme parasit yang terdapat pada tanah tersebut. Prototipe pupuk hayati mikoriza di aplikasikan pada tanaman jagung untuk mengetahui efektifitasnya setelah diberikan perlakuan lama penyimpanan dan media pembawa pada tanaman jagung. Pengaplikasian ini dilakukan selama 2 bulan.

Variabel yang diamati pada penelitian ini adalah jumlah spora (buah), jumlah daun (helai), tinggi tanaman $(\mathrm{cm})$, diameter batang tanaman $(\mathrm{cm})$, klorofil daun (SPAD), berat segar akar $(\mathrm{g})$, berat kering akar $(\mathrm{g})$, berat segar tongkol $(\mathrm{g})$, berat kering tongkol $(\mathrm{g})$, berat segar brangkasan (g), berat kering brangkasan (g), infeksi akar (\%), jumlah akar (buah), panjang akar $(\mathrm{cm})$, berat segar total tanaman $(\mathrm{g})$, berat kering oven total tanaman (g).

Data hasil isolasi dan identifikasi ditabulasi dan dianalisis secara deskriptif, sedangkan data hasil uji efektifitas spora pada waktu simpan yang berbeda, variabel pertumbuhan tanaman dianalisis dengan menggunakan analisis sidik ragam, apabila terdapat pengaruh nyata, maka dilanjutkan dengan uji jarak berganda Duncan's.

\section{HASIL DAN PEMBAHASAN}

Hasil analisis statistika menunjukkan perlakuan media pembawa berpengaruh nyata terhadap variabel jumlah daun, klorofil daun, berat kering akar, dan berat segar tongkol tetapi berpengaruh tidak nyata terhadap variabel jumlah spora setelah penyimpanan, tinggi tanaman, diameter batang, berat segar akar, berat kering tongkol, berat segar brangkasan, berat kering brangkasan, infeksi akar, jumlah akar, panjang akar, berat segar total, dan berat kering total (Tabel 3.1).

Hasil analisis statistika menunjukkan, perlakuan lama penyimpanan berpengaruh nyata terhadap variabel jumlah spora setelah penyimpanan, berat tongkol kering dan infeksi akar tetapi berpengaruh tidak nyata terhadap variabel jumlah daun, tinggi tanaman, diameter batang, klorofil daun, berat segar akar, berat kering akar, berat segar tongkol, berat segar brangkasan, berat kering brangkasan, jumlah akar, panjang akar, berat segar total, dan berat kering total (Tabel 1).

Hasil analisis statistika menunjukkan adanya interaksi antara media pembawa dan lama penyimpanan berpengaruh nyata terhadap variabel diameter batang dan berat segar tongkol tetapi berpengaruh tidak nyata terhadap variabel jumlah spora setelah 
KADEK JUNIARI. et al. Uji Daya Simpan dan Efektivitas Prototipe Pupuk Hayati...

penyimpanan, jumlah daun, tinggi tanaman,

Pada perlakuan media pembawa tinggi klorofil daun, berat segar akar, berat kering tanaman dan berat kering tongkol pada pasir akar, berat kering tongkol, berat segar vulkanik lebih tinggi dibandingkan dengan brangkasan, berat kering brangkasan, infeksi akar, jumlah akar, panjang akar, berat segar tinggi tanaman dan berat kering tongkol pada pasir laut tetapi secara statistika berbeda total, dan berat kering total (Tabel 1).

tidak nyata. Pada perlakuan lama

Pada perlakuan media pembawa jumlah spora setelah penyimpanan selama 1 bulan, 2 bulan, dan 3 bulan pada pasir vulkanik lebih tinggi dibandingkan dengan pasir laut tetapi secara statistika berbeda tidak nyata. Pada perlakuan lama penyimpanan semakin lama spora disimpan jumlah spora semakin kecil. Jumlah spora tertinggi didapatkan pada lama penyimpanan 1 bulan dan berbeda nyata penyimpanan semakin lama spora disimpan tinggi tanaman dan berat kering tongkol semakin kecil. Tinggi tanaman dan berat kering tongkol tertinggi setelah penyimpanan didapatkan pada lama penyimpanan 1 bulan berbeda tidak nyata dengan lama penyimpanan 2 bulan akan tetapi berbeda nyata dengan lama penyimpanan 3 bulan (Tabel 2).

dengan lama penyimpanan selama 2 bulan dan 3 bulan (Tabel 2).

Jumlah daun pada perlakuan media pembawa pasir vulkanik lebih tinggi dibandingkan dengan jumlah daun pada media pembawa pasir laut dan secara statistika berbeda nyata. Pada perlakuan lama penyimpanan jumlah daun tertinggi didapatkan pada lama penyimpanan 3 bulan tetapi berbeda tidak nyata dengan lama penyimpanan selama 2 bulan dan 3 bulan. Semakin lama spora disimpan jumlah daun cenderung semakin kecil (Tabel 2). 
Tabel 1. Signifikansi Pengaruh Media Pembawa, Lama Penyimpanan, dan Interaksi terhadap Variabel Pertumbuhan Tanaman Indikator

\begin{tabular}{|c|c|c|c|c|}
\hline \multirow[t]{2}{*}{ No } & \multicolumn{4}{|c|}{ Perlakuan } \\
\hline & Variabel & $\begin{array}{c}\text { Media } \\
\text { Pembawa }\end{array}$ & $\begin{array}{c}\text { Lama } \\
\text { Penyimpanan }\end{array}$ & Interaksi \\
\hline 1 & Jumlah spora (buah) & ns & $* *$ & ns \\
\hline 2 & Jumlah daun (helai) & $* *$ & ns & ns \\
\hline 3 & Tinggi tanaman $(\mathrm{cm})$ & ns & ns & ns \\
\hline 4 & Diameter batang $(\mathrm{cm})$ & ns & ns & $* *$ \\
\hline 5 & Klorofil daun (SPAD) & $* *$ & ns & ns \\
\hline 6 & Berat segar akar (g) & ns & ns & ns \\
\hline 7 & Berat kering akar $(\mathrm{g})$ & $* *$ & ns & ns \\
\hline 8 & Berat segar tongkol $(\mathrm{g})$ & $* *$ & ns & $* *$ \\
\hline 9 & Berat kering tongkol $(\mathrm{g})$ & ns & $* *$ & ns \\
\hline 10 & Berat segar brangkasan $(\mathrm{g})$ & ns & ns & ns \\
\hline 11 & Berat kering brangkasan $(\mathrm{g})$ & ns & ns & ns \\
\hline 12 & Infeksi akar (\%) & ns & $* *$ & ns \\
\hline 13 & Jumlah akar (buah) & ns & ns & ns \\
\hline 14 & Panjang akar $(\mathrm{cm})$ & ns & ns & ns \\
\hline 15 & Berat segar total tanaman $(\mathrm{g})$ & ns & ns & ns \\
\hline 16 & Berat kering total tanaman $(\mathrm{g})$ & ns & ns & ns \\
\hline
\end{tabular}

Klorofil daun dan berat kering akar pada perlakuan media pembawa pasir vulkanik lebih tinggi dibandingkan dengan klorofil daun dan berat kering akar pada media pembawa pasir laut dan secara statistika berbeda nyata. Pada perlakuan lama penyimpanan klorofil daun dan berat kering akar tertinggi didapatkan pada lama penyimpanan 1 bulan tetapi berbeda tidak nyata dengan lama penyimpanan selama 2 bulan dan 3 bulan.Semakin lama spora disimpan klorofil daun dan berat kering akar semakin kecil (Tabel 2).
Pada perlakuan media pembawa berat segar akar pada pasir laut lebih tinggi dibandingkan dengan berat segar akar pada media pembawa pasir vulkanik tetapi secara statistika berbeda tidak nyata. Pada perlakuan lama penyimpanan semakin lama spora disimpan berat segar akar semakin kecil. Berat segar akar tertinggi didapatkan pada lama penyimpanan 1 bulan tetapi berbeda tidak nyata dengan lama penyimpanan selama 2 bulan dan 3 bulan (Tabel 2).

Berat segar brangkasan, jumlah akar, dan berat segar total pada perlakuan media 
KADEK JUNIARI. et al. Uji Daya Simpan dan Efektivitas Prototipe Pupuk Hayati...

pembawa pasir vulkanik lebih tinggi penyimpanan semakin lama spora disimpan dibandingkan dengan berat segar berat kering brangkasan, panjang akar, dan brangkasan, jumlah akar, dan berat segar berat kering total cenderung menurun. Berat total pada media pembawa pasir laut tetapi kering brangkasan, panjang akar, dan berat secara statistika berbeda tidak nyata. Pada kering total tertinggi setelah penyimpanan perlakuan lama penyimpanan berat segar didapatkan pada lama penyimpanan 2 bulan brangkasan, jumlah akar, dan berat segar tetapi secara statistika berbeda tidak nyata total tertinggi didapatkan pada lama dengan lama penyimpanan selama 1 bulan penyimpanan 1 bulan tetapi secara statistika berbeda tidak nyata dengan lama penyimpanan selama 2 bulan dan 3 bulan. Semakin lama spora disimpan berat segar brangkasan, jumlah akar, dan berat segar total dan jumlah akar semakin kecil (Tabel 3).

Pada perlakuan media pembawa berat kering brangkasan, panjang akar, dan berat kering total pada pasir vulkanik lebih tinggi dibandingkan dengan berat kering brangkasan, panjang akar, dan berat kering total pada pasir laut tetapi secara statistika dan 3 bulan (Tabel 3).

Infeksi akar pada perlakuan media pembawa pasir vulkanik lebih tinggi dibandingkan dengan infeksi akar pada media pembawa pasir laut tetapi secara statistika berbeda tidak nyata.Pada perlakuan lama penyimpanan infeksi akar tertinggi didapatkan pada lama penyimpanan 1 bulan tetapi secara statistika berbeda tidak nyata dengan lama penyimpanan selama 2 dan berbeda nyata dengan lama penyimpanan 3 bulan. Semakin lama spora disimpan infeksi akar semakin kecil (Tabel 3).

berbeda tidak nyata. Pada perlakuan lama 
AGROTROP, 10 (2): 165 - 177 (2020)

Tabel 2. Jumlah Spora Setelah Penyimpanan dan Variabel Pertumbuhan Tanaman Indikator dengan Media Pembawa yang Berbeda dan Lama Penyimpanan yang Berbeda

\begin{tabular}{|c|c|c|c|c|c|c|c|}
\hline Perlakuan & $\begin{array}{c}\text { Jumlah } \\
\text { spora } \\
\text { (buah) }\end{array}$ & $\begin{array}{c}\text { Jumlah } \\
\text { Daun } \\
\text { (helai) }\end{array}$ & $\begin{array}{l}\text { Tinggi } \\
\text { Tanam- } \\
\text { an }(\mathrm{cm})\end{array}$ & $\begin{array}{l}\text { Klorofil } \\
\text { Daun } \\
\text { (SPAD) }\end{array}$ & $\begin{array}{c}\text { Berat } \\
\text { Segar } \\
\text { Akar } \\
(\mathrm{g})\end{array}$ & $\begin{array}{l}\text { Berat } \\
\text { Kering } \\
\text { Akar } \\
(\mathrm{g})\end{array}$ & $\begin{array}{c}\text { Berat } \\
\text { Kering } \\
\text { Tongkol } \\
\text { (g) }\end{array}$ \\
\hline \multicolumn{8}{|c|}{ Media pembawa } \\
\hline $\mathrm{V}$ & 78,06 a & $11,50 \mathrm{a}$ & $147,67 \mathrm{a}$ & $33,23 \mathrm{a}$ & $74,54 \mathrm{a}$ & $10,15 \mathrm{a}$ & $10,58 \mathrm{a}$ \\
\hline $\mathrm{L}$ & $74,44 \mathrm{a}$ & $10,22 \mathrm{~b}$ & $144,05 \mathrm{a}$ & $29,41 \mathrm{~b}$ & $83,17 \mathrm{a}$ & $7,99 \mathrm{~b}$ & $10,32 \mathrm{a}$ \\
\hline BNT 5\% & 8,25 & 1,21 & 9,25 & 3,43 & 23,93 & 1,96 & 3,53 \\
\hline \multicolumn{8}{|c|}{ Lama Penyimpanan } \\
\hline $\mathrm{S}_{1}$ & $85,00 \mathrm{a}$ & $10,83 \mathrm{a}$ & $152,67 \mathrm{a}$ & $33,23 \mathrm{a}$ & $82,54 \mathrm{a}$ & $9,92 \mathrm{a}$ & $12,64 \mathrm{a}$ \\
\hline $\mathrm{S}_{2}$ & $72,08 \mathrm{~b}$ & $10,58 \mathrm{a}$ & $145,50 \mathrm{a}$ & $31,06 \mathrm{a}$ & $81,56 \mathrm{a}$ & $8,75 \mathrm{a}$ & $11,65 \mathrm{a}$ \\
\hline $\mathrm{S}_{3}$ & $71,67 \mathrm{~b}$ & $11,17 \mathrm{a}$ & $139,42 \mathrm{~b}$ & $29,67 \mathrm{a}$ & $72,45 \mathrm{a}$ & $8,54 \mathrm{a}$ & $7,05 \mathrm{~b}$ \\
\hline BNT 5\% & 10,11 & 1,48 & 11,33 & 4,20 & 29,31 & 2,39 & 4,33 \\
\hline
\end{tabular}

Keterangan: Angka yang diikuti huruf yang berbeda pada perlakuan dan kolom yangsama menunjukkan berbeda nyata pada uji beda nyata terkecil (BNT) taraf $5 \%$.

Tabel 3. Jumlah Spora Setelah Penyimpanan dan Variabel Pertumbuhan Tanaman Indikator dengan Media Pembawa yang Berbeda dan Lama Penyimpanan yang Berbeda

\begin{tabular}{|c|c|c|c|c|c|c|c|}
\hline Perlakuan & $\begin{array}{c}\text { Berat } \\
\text { segar } \\
\text { Brangka- } \\
\text { san }(\mathrm{g})\end{array}$ & $\begin{array}{c}\text { Berat } \\
\text { Kering } \\
\text { Brangka } \\
\text { San }(g)\end{array}$ & $\begin{array}{c}\text { Infeksi } \\
\text { Akar } \\
(\%)\end{array}$ & $\begin{array}{l}\text { Jumlah } \\
\text { Akar } \\
\text { (buah) }\end{array}$ & $\begin{array}{c}\text { Panjang } \\
\text { Akar } \\
(\mathrm{cm})\end{array}$ & $\begin{array}{l}\text { Berat } \\
\text { Segar } \\
\text { Total } \\
(\mathrm{g}) \\
\end{array}$ & $\begin{array}{c}\text { Berat } \\
\text { kering } \\
\text { Total } \\
(\mathrm{g}) \\
\end{array}$ \\
\hline \multicolumn{8}{|c|}{ Media pembawa } \\
\hline V & $130,33 \mathrm{a}$ & 44,52 a & 83,33 a & 38,56 a & $28,58 \mathrm{a}$ & $261,07 \mathrm{a}$ & $65,25 \mathrm{a}$ \\
\hline $\mathrm{L}$ & $129,81 \mathrm{a}$ & $42,68 \mathrm{a}$ & $82,22 \mathrm{a}$ & $33,50 \mathrm{a}$ & $27,47 \mathrm{a}$ & $255,59 \mathrm{a}$ & $60,98 \mathrm{a}$ \\
\hline BNT 5\% & 35,82 & 11,71 & 5,73 & 6.62 & 4,11 & 55,22 & 14,69 \\
\hline \multicolumn{8}{|c|}{ Lama Penyimpanan } \\
\hline $\mathrm{S}_{1}$ & $135,88 \mathrm{a}$ & 41,89 a & $88,33 \mathrm{a}$ & 38,33 a & $28,04 \mathrm{a}$ & $272,13 \mathrm{a}$ & 64,46 a \\
\hline $\mathrm{S}_{2}$ & $127,29 \mathrm{a}$ & $45,85 \mathrm{a}$ & $83,33 \mathrm{a}$ & $35,50 \mathrm{a}$ & $28,05 \mathrm{a}$ & $255,89 \mathrm{a}$ & $66,25 \mathrm{a}$ \\
\hline $\mathrm{S}_{3}$ & $127,05 \mathrm{a}$ & $43,05 \mathrm{a}$ & $76,67 \mathrm{~b}$ & $34,25 \mathrm{a}$ & $27,99 \mathrm{a}$ & $246,99 \mathrm{a}$ & $58,64 \mathrm{a}$ \\
\hline BNT 5\% & 43,87 & 14,35 & 7,02 & 8,11 & 5,04 & 67,63 & 17,99 \\
\hline
\end{tabular}

Keterangan: Angka yang diikuti huruf yang berbeda pada perlakuan dan kolom yang sama menunjukkan berbeda nyata pada uji beda nyata terkecil (BNT) taraf 5\%.

Pada perlakuan media pembawa diameter batang pada pasir vulkanik berbeda tidak nyata antara penyimpanan selama 1 bulan, 2 bulan, dan 3 bulan tetapi pada media pembawa pasir laut semakin lama spora disimpan dari 1 bulan sampai 3 bulan maka 


\section{KADEK JUNIARI. et al. Uji Daya Simpan dan Efektivitas Prototipe Pupuk Hayati...}

diameter batang yang dihasilkan semakin kecil. Tabel 3.4 menunjukkan pada media pembawa pasir laut yang disimpan selama 1 bulan diameter batang yang dihasilkan adalah 3,04 $\mathrm{cm}$ sedangkan diameter batang pada penyimpanan 2 bulan dan 3 bulan masing-masing $3,02 \mathrm{~cm}$ dan $2,83 \mathrm{~cm}$.

Pada perlakuan media pembawa pasir vulkanik berat segar tongkol tertinggi diperoleh pada lama penyimpanan selama 2 bulan (71,93 g) lebih tinggi dibandingkan dengan lama penyimpanan selama 1 bulan $(55,75 \mathrm{~g})$ walaupun secara statistika berbeda tidak nyata dan berat segar tongkol terendah diperoleh pada lama penyimpanan 3 bulan (40,95 g). Pada media pembawa pasir laut berat segar tongkol tertinggi diperoleh pada lama penyimpanan selama 3 bulan $(54,02 \mathrm{~g})$ lebih tinggi dibandingkan dengan lama penyimpanan 1 bulan (51,67 g) walaupun secara statistika berbeda tidak nyata dan berat segar tongkol terendah diperoleh pada lama penyimpanan 2 bulan yaitu 22,16 g (Tabel 4).

Tabel 4. Diameter Batang dan Berat Segar Tongkol pada Media Pembawa yang Berbeda dan Lama Penyimpanan yang Berbeda

\begin{tabular}{ccccccc}
\hline & \multicolumn{4}{c}{ Diameter batang $(\mathrm{cm})$} & \multicolumn{2}{c}{ Berat segar tongkol $(\mathrm{g})$} \\
\hline Perlakuan & & $\mathrm{V}$ & $\mathrm{L}$ & $\mathrm{V}$ & $\mathrm{L}$ \\
& $\mathrm{S}_{1}$ & & $2,81 \mathrm{~b}$ & $3,04 \mathrm{a}$ & $55,75 \mathrm{ab}$ & $51,67 \mathrm{~b}$ \\
& $\mathrm{~S}_{2}$ & & $3,02 \mathrm{ab}$ & $3,02 \mathrm{ab}$ & $71,93 \mathrm{a}$ & $22,16 \mathrm{c}$ \\
& $\mathrm{S}_{3}$ & & $3,00 \mathrm{ab}$ & $2,83 \mathrm{ab}$ & $40,95 \mathrm{~b}$ & $54,02 \mathrm{~b}$ \\
\hline
\end{tabular}

Keterangan: Angka yang diikuti huruf yang berbeda pada diameter batang dan berat segar tongkol menunjukkan berbeda nyata pada uji jarak berganda Duncan's (UJBD) taraf 5\%.

Berdasarkan hasil uji daya simpan spora FMA dan uji efektifitasnya pada tanaman jagung dengan media pembawa pasir vulkanik dan pasir laut menunjukkan bahwa pasir vulkanik lebih baik digunakan sebagai media pembawa spora FMA dibandingkan menggunakan media pembawa pasir laut, hal tersebut terlihat dari hasil analisis statistika dimana hampir semua variabel pengamatan menunjukkan hasil yang lebih baik menggunakan media pembawa pasir vulkanik seperti jumlah spora setelah penyimpanan ( 1 bulan, 2 bulan, dan 3 bulan), jumlah daun, tinggi tanaman, klorofil daun, berat kering akar, berat kering tongkol, berat segar brangkasan, infeksi akar, jumlah akar, panjang akar berat segar total dan berat kering total. Pasir vulkanik juga merupakan bahan yang kaya akan unsur hara sehingga berpotensi meningkatkan kesuburan tanah pertanian di kemudian hari dan dapat memperbaharui sumber daya tanah (Munir, 1996). Komponen material yang dikandung di antaranya kuarsa $\left(\mathrm{SiO}_{2}\right)$, aluminium oksida $\left(\mathrm{Al}_{2} \mathrm{O}_{3}\right)$, besi oksida $\left(\mathrm{Fe}_{2} \mathrm{O}_{3}\right)$ dalam jumlah sangat tinggi, selain juga terkandung 
unsur $\mathrm{Ca}, \mathrm{Mg}, \mathrm{Na}$ serta material lainnya (Hartosuwarno, 2010). Mineral pasir vulkanik memiliki fraksi yang didominasi oleh sebagaian besar pasir dengan kejenuhan basa dan kandungan silika yang tinggi. Fungsi pasir vulkanik selain mampu memperbaiki struktur, mengurangi efek racun asam-asam organik dan lain sebagainya, sedangkan pasir laut cenderung bersifat basa karena kandungan garamnya yang tinggi dan sedikitnya partikel liat. Hasil penelitian Zuraida menunjukkan bahwa pemanfaatan pasir vulkanik Kelud hasil letusan pada tahun 1990 dapat meningkatkan tinggi tanaman dan bobot kering tanaman. Pasir vulkanik dengan tekstur kasar dan unsur hara yang rendah sehingga sangat baik sebagai medium tumbuh untuk produksi inokulum mikoriza arbuskula. Sedikitnya kadar air dan tingginya konsentrasi garam dalam pasir laut dapat mengakibatkan tumbuhan mengalami kekeringan karena potensi osmotik tanah lebih tinggi daripada potensi osmotik jaringan sehingga menghambat penyerapan air dan unsur-unsur hara. Selain itu, kadar bahan organik dalam tanah pasir yang sedikit dapat mengganggu aktivitas fisiologi tumbuhan yang berupa laju transpirasi, laju respirasi, laju fotosintesis dan sintesis protein, sehingga hasil pertumbuhan tanamannya kurang baik.

Berdasarkan hasil daya simpan spora FMA bergenus Glomus selama 1 bulan, 2 bulan, dan 3 bulan menunjukkan bahwa penyimpanan 1 bulan lebih baik dibandingkan penyimpanan selama 2 bulan dan 3 bulan, hal tersebut terlihat dari hasil analisis statistika pada variabel jumlah spora setelah penyimpanan menunjukkan hasil $S_{1}$, $\mathrm{S}_{2}$ dan $\mathrm{S}_{3}$ masing-masing 85,00 buah, 72,08 buah dan 71,67 buah (Tabel 3.2) disamping itu pada variabel pertumbuhan tanaman indikator juga menunjukkan pengaruh yang lebih baik, seperti tinggi tanaman, klorofil daun, berat segar akar, berat kering akar, berat kering tongkol, berat segar brangkasan, infeksi akar, jumlah akar, dan berat segar total. Penyimpanan spora FMA 1 bulan menunjukkan penyimpanan yang paling efektif dibandingkan penyimpanan selama 2 bulan atau 3 bulan, karena semakin cepat spora FMA diaplikasikan maka hasilnya semakin baik, lebih efektif dan sebaliknya semakin lama penyimpanan spora FMA disimpan maka hasilnyan kurang baik, apabila semakin lama spora FMA disimpan mengakibatkan adanya kerusakan atau pecah pada spora tersebut sehingga kurangnya peranan spora pada tanaman indikator yang diakibatkan karena jumlah spora yang ada 


\section{KADEK JUNIARI. et al. Uji Daya Simpan dan Efektivitas Prototipe Pupuk Hayati...}

juga berkurang.Lama penyimpanan akan menurunkan viabilitas spora FMA. Spora merupakan propagul yang mampu bertahan hidup lebih lama dibandingkan dengan hifa yang ada di dalam akar ataupun di dalam tanah. Perkecambahan spora bergantung pada lingkungan, seperti $\mathrm{pH}$, temperatur, dan kelembaban tanah serta kadar bahan organik (Smith dan Read, 2008). Waktu penyimpanan menyangkut umur inokulan apakah masih dapat digunakan. Bila penyimpanan spora FMA semakin lama maka mutu (keefektifan) inokulan cenderung semakin menurun.

Interaksi antara media pembawa dan lama penyimpanan tidak berpengaruh nyata terhadap beberapa variabel pengamatan akan tetapi berpengaruh nyata terhadap diameter batang dan berat segar tongkol. Berat segar tongkol pada media pembawa pasir vulkanik dengan lama penyimpanan selama 2 bulan menunjukkan hasil yang terbaik sedangkan pada media pembawa pasir laut dengan lama penyimpanan selama 2 bulan justru menunjukkan hasil terendah, hal ini menunjukkan bahwa lama penyimpanan tidak konsisten apabila menggunakan media yang berbeda dan perbedaan media pembawa memerlukan lama penyimpan yang berbeda pula. Penelitian terhadap pengaruh mikoriza terhadap pertumbuhan tanaman jagung juga pernah dilaporkan oleh Farida dan Chozin (2015) yang menunjukkan bahwa pemberian FMA secara statistika tidak menunjukkan pengaruh nyata, namun hasil rata-rata menunjukkan tanaman jagung yang diberi FMA menghasilkan pertumbuhan dan produksi jagung yang lebih tinggi dibandingkan tanpa FMA.

\section{SIMPULAN}

Berdasarkan hasil penelitian ini, dapat disimpulkan yaitu media pembawa pasir vulkanik lebih baik daripada media pembawa pasir laut, hal ini ditunjukkan oleh berat kering total yang hasilnya lebih baik. Umur simpan yang terbaik prototipe pupuk hayati yang berasal dari perakaran salak adalah umur simpan 1 bulan, hal ini ditunjukkan oleh jumlah spora setelah penyimpanan. Terjadi interaksi antara media pembawa dan lama penyimpanan terhadap diameter batang tanaman dan berat segar tongkol tanaman. Berat segar tongkol tertinggi, yaitu 71,93 g/tanaman diperoleh pada perlakuan kombinasi media pembawa pasir vulkanik dengan penyimpanan 2 bulan.

\section{DAFTAR PUSTAKA}

Agrofarm. (2014). Lampaui Rekor Tertinggi Impor Jagung Capai 3,6 Juta Ton. Majalah Agrofarm. (http://www. agrofarm.co.id) 
Chalimah. S. (2007). Perbanyakan Gigaspora sp dan Acaulospora. Surakarta: FMIPA UNS Surakarta.

Farida, R dan Chozin, M.A. (2015). Pengaruh pemberian cendawan mikoriza arbuskula (CMA) dan dosis pupuk kandang ayam terhadap pertumbuhan dan produksi jagung (Zea mays). Bul. Agrohorti. 3(3). Hal: 323329.

Hartosuwarno. (2010). Sifat fisik dan Komposisi Abu vulkanik Gunung Merapi. Kampus UPNVY 16 (118): 5.

Munir, M. (1996). Tanah-Tanah Utama Indonesia. Dunia Pustaka Jaya, Jakarta

Musfal. (2010). Potensi cendawan mikoriza arbuskula untuk meningkatkan hasil tanaman jagung. Jurnal Litbang Pertanian 29 (4): 154-158.

Natalia, N. (2016). Eksplorasi Fungi Mikoriza Arbuskula (FMA) di Hutan Pendidikan Mangrove Unila Desa Margasari Kabupaten Lampung Timur. Skripsi. Fakultas Pertanian. Universitas Lampung. Bandar Lampung.

Pacioni, G. (1992). Wet Sieving and Decanting Techniques for the Extraction of Spores of VA Mycorrhyzal Fungi. Methods in Microbiology. Academic Press Inc. San Diego 24: 317-322.

Pangaribuan. (2014). Trapping of Indigenus Arbuscular Mycoriza Fungi Fromphysic Corn and Nuts at Peatland West Kalimantan.

Smith, S.E., Read D.J. (2008). Mycorrhizal Symbiosis. London (GB). Academic Press.

Zuraida. (1999). Penggunaan Abu Vulkan sebagai Amelioran pada Tanah Gambut dan Pengaruhnya terhadap Sifat Kimia Tanah dan Pertumbuhan Jagung. Skripsi. Institut Pertanian Bogor. Bogor 